\title{
LAND USE DYNAMICS IN THE DEHESAS IN THE SIERRA MORENA (SPAIN): THE ROLE OF DIVERSE MANAGEMENT STRATEGIES TO COPE WITH THE DRIVERS OF CHANGE
}

\author{
Christoph Schröder ${ }^{1}$
}

Received 9 April 2011; Accepted 23 September 2011

\begin{abstract}
The dehesa in the southwestern Iberian Peninsula represents both a unique agrosilvopastoral land-use and a rural social-ecological system. Over the last 60 years, the dehesa has experienced profound modifications of its overall structure, affecting the resilience of the system. Based on land change analysis combined with interviews with land managers, the paper gives insights on how the dehesa has been modified by the combination of land-users' strategies and driving forces on different scales, using a political-ecological approach. The results of the cross-scale analysis suggest that land dynamics are highly differentiated spatially and temporally due to a diversity of management strategies and actors' attitudes towards conservation and innovation. The development of the dehesa has to come along with an active use of its resources. Furthermore, European policy for agriculture and local development must be sensible to regional land-use system's idiosyncrasy as they are the key factors for the dehesa's future.
\end{abstract}

Key Words: Dehesa, Land change, Political Ecology, Land-Use Change, Resilience, Socialecological systems, Adaptive management strategies

Resumen:La dehesa del suroeste de la Península Ibérica representa un único sistema agrosilvopastoril de aprovechamiento del monte mediterráneo asociado a un sistema socio-ecológico específico en el mundo rural español. La dehesa ha experimentado transformaciones profundas de su estructura general durante los últimos sesenta años, que han afectado la resiliencia del sistema. A partir de los datos del análisis del cambio de uso del suelo que se combinó con entrevistas con gestores de fincas, el artículo se centra en cómo la dehesa se ha modificado debido a la combinación de estrategias de manejo y gestión en las fincas y de las fuerzas exteriores, utlizando un planteamiento político-ecológico. Los resultados del análisis sugieren que las dinámicas de uso están diferenciadas temporal y espacialmente debido a la diversidad de estrategias de adaptación y mitigación a nivel de finca y de las actitudes de los actores hacia la conservación e innovación. El desarrollo de la dehesa tiene que ir acompañado con un uso active de sus recursos. Además, la

\footnotetext{
${ }^{1}$ Christoph Schröder, Research Group "Territorial Structures and Systems" (http://grupo.us.es/giest/), Universidad Pablo de Olavide, Laboratorio de Geografía "Prof. Eulogio Parrilla", Carretera de Utrera, km 1, 41013 Sevilla (Spain), e-mail: csch1@upo.es
} 
política europea en materia de agricultura y desarrollo local tiene que ser respetuoso con sistemas locales específicos como son la clave para el futuro de la dehesa.

Palabras claves: Dehesa, Cambio de uso del suelo, Ecología Política, Resiliencia, Sistemas socio-ecológicos, Gestión adaptativa

\section{Introduction}

European agrosilvopastoral systems are currently undergoing a far-reaching transition that involves changes in land use and management practices. These land-use systems are especially notable in the Mediterranean countries (Caraveli 2000, Plieninger \& Hall Beyer 2007). In Spain, 20 million of its 34 million hectares of agricultural land remain dedicated to low intensive farming (Beaufoy 1995). Most representative of these low-intensive agrarian landscapes is the dehesa which, if its Portuguese equivalent the montado is included, covers more than six million hectares in the southwestern part of the Iberian Peninsula (Sundseth 2009). The dehesa is a fundamental part of rural culture and economy and has historical importance in this entire zone (San Miguel 1994). The integrated resource management, its high biodiversity and cultural and socio-economic importance for the region's development characterise the idiosyncrasy of the dehesa as a Mediterranean cultural landscape (Plieninger \& Wilbrand 2001, Blondel 2006). Its conservation and development depends on the dehesa's multifunctional nature which maintains at the same time its diversity as an extraordinary habitat for birds and mammals (Díaz, Campos \& Pulido 1997, Oudenhoven, Mijatovic \& Eyzaguirre 2010).

In recent years, the dehesa has attracted new interest because of its landscape character and value for nature conservation (Olea \& San Miguel-Ayanz 2006). While the European Union has promoted this system as a model for extensive and sustainable land use in Europe's rural areas (European Council 2006), European and national public policies have actually put in danger the dehesa's multifunctionality and its value as an ecosystem and a cultural landscape (Peco, Oñate \& Requena 2001, Euronatur, Fundación Mediterráneo \& WWF 2006). In an ecologically sensitive region like the summer-dry subtropics, the implementation of contradictory agricultural and conservation policies risks triggering desertification and the unpredictable effects of global change (Zavala et al. 2004, Caraveli 2000).

Given this setting, the dualistic extensification-intensification debate (Pinto \& Mascarenhas 1999, Papanastasis 2004) biases the scientific discourse over land-use dynamics and the past and present situation of the dehesa. The same holds true for its ostensible character of sustainability and "paradigm of successful co-evolution" (Pérez, San Miguel \& Elena-Rosselló 2007) or its notion as underdeveloped and marginalised region (Ojeda \& Silva 1997). This paper seeks to overcome these debates as it conceives the dehesa as an integrated land-use system characterized by cross-scale interactions between the ecological and socioeconomic components (Blondel 2006, Gastó et al. 2008). It aims to shed light on the diversity of responses of different local land managers to ongoing socio-economic changes on the regional and supra-regional level. For this purpose, it examines actors and driving forces involved in land dynamics, as illustrated by the case of land-use change in the Dehesas of the Sierra Morena, near the second half of the twentieth century.

The paper is based on field work and GIS-analysis of land-use changes on a selection of farms in the Biosphere Reserve "Dehesas de Sierra Morena" in western Andalusia. It is divided in four parts. First the conceptual framework is discussed and the general characteristics and developments of the dehesa are presented. Second, the methodology of the research is explained. In the result section, different types of land management strategies are analysed and characterized. In a further step, the environmental outcomes of different management strategies are contrasted with the land manager's attitude and the overall socio-economic processes by examining which actors and driving forces affect land-use decisions and the spatial and temporal scales at which these drivers act. Finally, the results are discussed and a conclusion presented. 


\section{Actors, drivers and scales of change}

The identification of actors and drivers and the scale they are located is crucial to any land change analysis (Hersperger et al. 2010). In the following section, the main concepts of political ecology in the context of land change analysis are explained. Particularly, in this paper, the agent - and institution-based analytical framework used in political ecology is applied to disentangle the complexity of the proximate causes (land-use decisions, management strategies, etc.) and the underlying driving forces (policies, climate change, market changes, etc.) of land-use dynamics. This approach offers a structured conceptualisation of the external factors influencing local actors, its land-use decisions and the following environmental change (Fig. 1), and is the basic principle for any political-ecological analysis (Blaikie \& Brookfield 1987, Krings 2000).

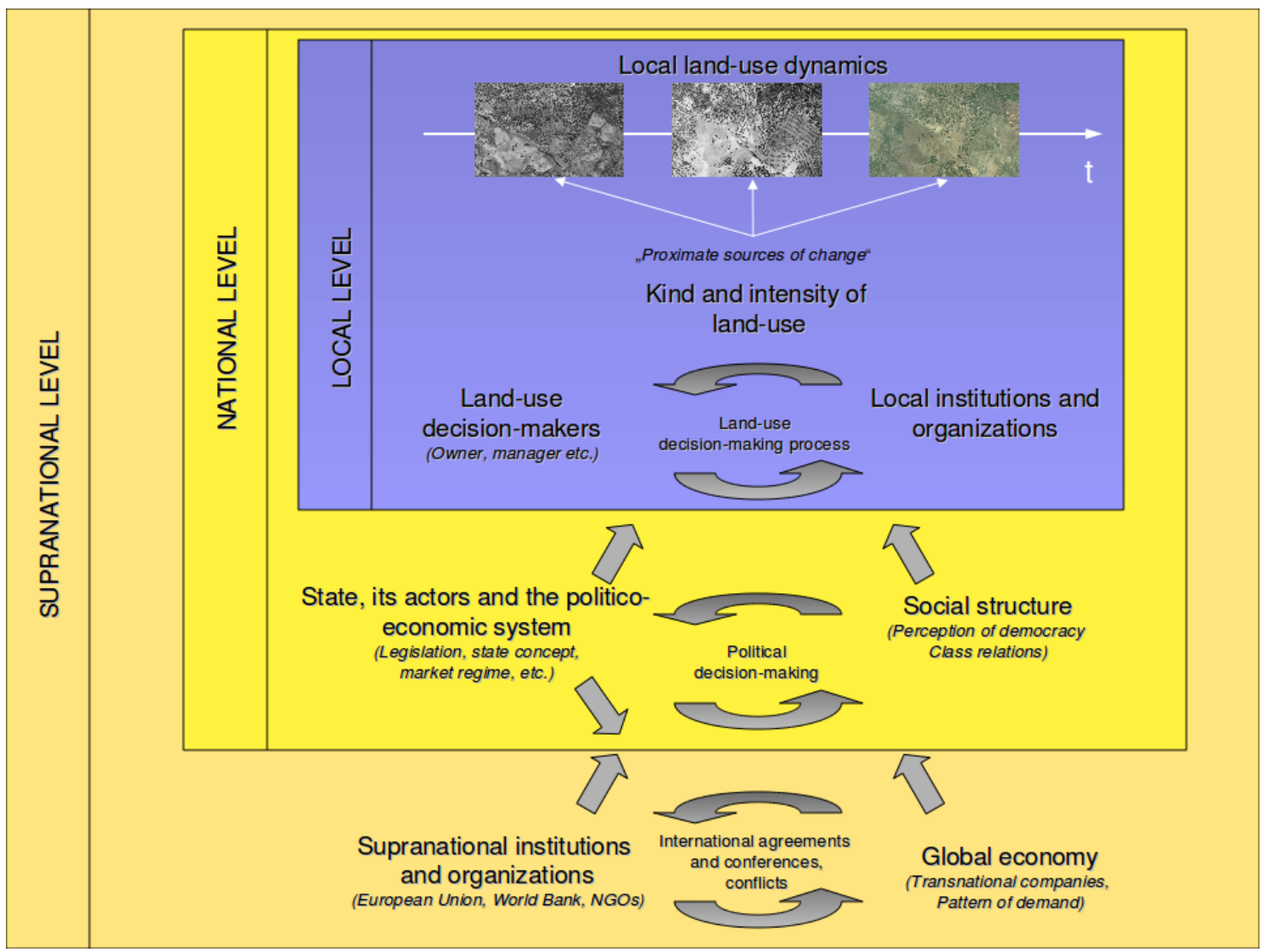

Fig 1. Multiscale explanation chain of land-use dynamics (source: own after Krings 2000).

Political Ecology is concerned with the power relations within which higher-level drivers (e.g. world market, European policies) interact and influence local communities and conditions (Blaikie \& Brookfield 1987, Escobar 1999). It essentially focuses on actors and drivers of environmental change on different levels of scales (Geist 1999). Bryant \& Bailey (1997) differentiate various types of actors influencing land changes. On the one hand, landowners and managers are defined as land-based actors in as much as a) the natural resources satisfy part of their basic needs and b) their decisions about type and intensity of land-use directly alter the existing land cover. The group of the land owners and land managers that are tied to their property but are not embedded in local society (mainly owners of large estates) are defined here as quasi-place-based actors. They neither are linked to the local settings nor are part of the external actors. Local institutions such as governments, companies or cooperative societies are place-based-actors that do not directly influence land-use and land-cover, but are of major importance as filters of regional and global dynamics (Pretty \& Ward 2003). The presence or absence of these institutions determines whether local communities and their associated landscapes can cope with external impacts (Fabricius et al. 2007, Newman \& Dale 2005). 
On the other end of the continuous line of actors, we can identify non-place-based actors. In the political-ecological framework the state is the most important representative of this kind of actors because it "[...] often has its own political, economic and strategic interests that derive from its unique socio-spatial position at the intersection of domestic political order and the interstate system" (Bryant \& Bailey 1997, p. 53). In the European context, the manifestation of the state, sometimes as regional government, as national authority or European Union makes its role and its socio-spatial position even more complex to analyse. The state establishes the legal framework for action and influences land-use decisions by offering incentives, imposing restrictions and defining general principles that result from forming a political will in which "[...] the state is the theatre in which resources, property rights and authority are struggled over" (Watts 1989 cit. in Graner 1997, p. 34).

The actors' interests and power relations change over time. Thus, with respect to both the analysis of land change and its driving forces, the whole complex of problems of scale must be focussed in detail (Lambin \& Geist 2001) in order to avoid false interpretation of change in complex systems. Concerning spatial scales, a series of studies on land cover changes in the Andalusian dehesas have shown the regional scale of landscape dynamics (Fernández Alés et al. 1992, Moreira \& González 1997, García del Barrio et al. 2004). Nevertheless, these analyses ignore the fact that a high spatial heterogeneity of land change is already present on the local level (Lambin \& Geist 2001). Abandonment and intensification may occur in the same municipality or even on the same management unit. These nuances cannot be distinguished using regionally or globally aggregated data. The same holds true for the state's role in incluencing land use strategies, as will be shown for the case of the dehesa.

As with spatial scales, multiple temporal scales are necessarily part of the analysis as data sets with different temporal ranges are collated (Crumley 2007). An analysis about a short time span may not show any changes at all while short-time modifications may be interpreted as trendsetting developments. Only long-term research allows for differentiating both trend fluctuations and transitional events from new realities or regime shifts (McNeill et al. 1994). Environmental change research should consider the close relationship with socio-economic aspects of change, in which time is not simply conceived of as discrete points in time when measurements are taken. Rather, the time scale is the social and environmental history of a specific place. This means that path dependency, the possibility of multiple states of equilibrium as well as individual lines of development are to be taken into consideration (Turner et al. 1995) A division of the local or regional temporal dimension is necessary to differentiate the "long-term perspective, short-term view of (multiple) eventism, and the medium-term span of cyclical changes" (Lohnert \& Geist 1999, p. 21).

\section{Methods}

In order to grasp the abovementioned complexity of scale, the methodology for this paper considered multiple temporal and spatial scales, using a triangulation of mapping, document analysis and in-depth interview techniques. The paper is based on field work and GIS-analysis of land-use changes on a selection of farms in the Biosphere Reserve "Dehesas de Sierra Morena" in western Andalusia. The selection of cases does not claim for representativeness as it looks for the maximal variation of cases. The goal was to assure the inclusion of the most relevant cases concerning the research questions and the regional setting using a cross-table, comparing the most important distinguishing features (Swanborn 2010). In the case of the dehesa, these features are land-use and type of property (Tab. 1). This theoretical selection was filled with cases by penetrating the research area by and by, following the principle of saturation (ibid.) and given the accessibility of the interviewees.

The author conducted ten in-depth interviews with land managers of the selected farms in order to record the history of these dehesas over the last 50 years. The analysis of the interviews led to a typology of land management strategies (see below) which was the basis for the GIS analysis of land-use changes on a selected farm of each type. Finally, the analysis of the specific actor constellation of these farms followed the explanation chain of the political ecology. In addition, the author held interviews with regional stakeholders and reviewed secondary documents to triangulate and substantiate facts from the interviews. 


\begin{tabular}{|l|c|c|c|c|}
\cline { 2 - 5 } \multicolumn{1}{c|}{} & \multicolumn{4}{c|}{ Owner type } \\
\hline $\begin{array}{l}\text { Actual land- } \\
\text { use }\end{array}$ & $\begin{array}{c}\text { External large-estate } \\
\text { owner (sideline basis) }\end{array}$ & $\begin{array}{c}\text { Local farmer on } \\
\text { regular basis }\end{array}$ & $\begin{array}{c}\text { Local famer on } \\
\text { sideline basis }\end{array}$ & $\begin{array}{c}\text { New owners (local } \\
\text { and external) }\end{array}$ \\
\hline Dehesa use & & & 5 & 9 \\
\hline Traditional & 2 & 3,8 & $(\mathrm{x})$ & $1,6,10$ \\
\hline Ecological & $(-)$ & $(\mathrm{x})$ & $(\mathrm{x})$ & 1,7 \\
\hline Hunting & 5 & $(-)$ & $(\mathrm{x})$ & $1,7,10$ \\
\hline Reforestation & 5 & $(\mathrm{x})$ & & \\
\hline
\end{tabular}

1 - case ID

(-) sparsely occuring case

(x) possible feature combination, not considered

Tab 1. Case selection matrix.

\section{The dehesas of the Sierra Morena}

The Sierra Morena forms a region of transition between the Meseta and the Guadalquivir Basin (Joffre et al. 1988) (see fig. 2) both in terms of geological and ecological properties and in historic terms concerning its role as trade route between the two (Rivera 1992, Ojeda \& Silva 2002). The typical high variability of water supply, both seasonally and inter-annually, is the most important limitation to the land's productive use. Summer drought limits the distribution of trees to species well adapted to this Mediterranean zone (Marañon et al. 2004). The characteristic species are holm oak (Quercus ilex) and cork oak (Q. suber). This arboreous duo, together with grasses and shrubs, forms the foundation of the dehesa and serves as the food for livestock and source of cork and wood. (Joffre et al. 1988).

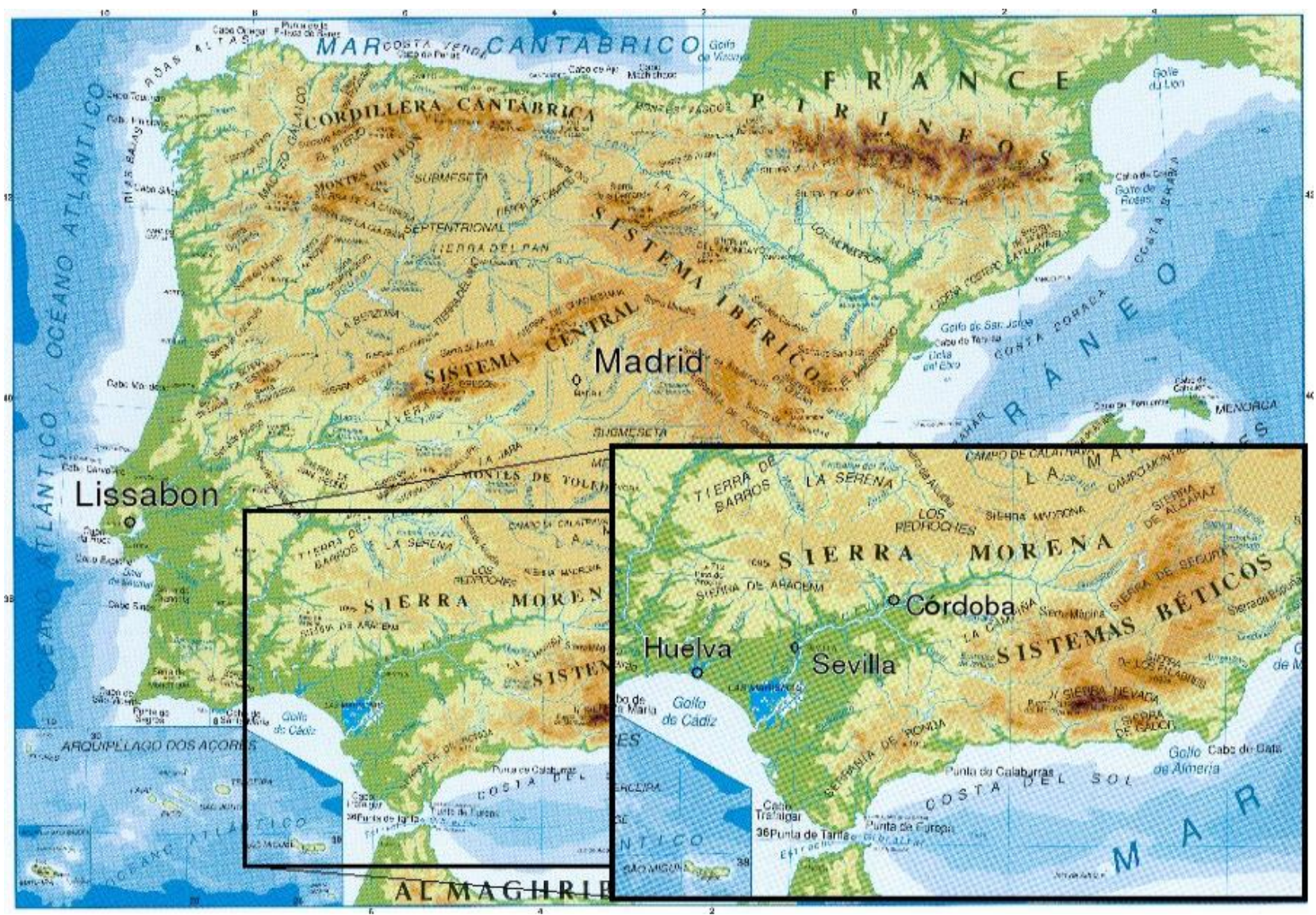

Fig 2. The Sierra Morena in the Iberian context (source: own).

The resource use under these conditions is based on a specific spatial and temporal management of multiple natural resources, following four use strategies (Parejo 1995): (a) complementarity in order to diversify the uses; (b) integrated resource use to avoid wasting available resources; (c) spatial organisation that links every animal and plant species to its 
specific location and; (d) temporal mobility to optimally use the seasonally differentiated resources. Fundamentally, within these basic strategies, the land-use system encompasses complementary livestock farming with sheep, cattle, goats and, above all, Iberian pigs, extensive agricultural cultivation and forest uses as cork and fire wood extraction (Fernández Alés 1997).

The availability of a cheap workforce, low regional inputs and stable market prices usually facilitated the integrated resource management (Acosta 2005). Despite the socio-economic dynamics that have taken place in Spain during the last fifty years, the temporally and spatially differentiated nature of the system has persisted over time and has resulted in high levels of biodiversity (Joffre et al. 1988). The structural diversity of the dehesa, with its mixture of open pastureland, scattered trees and dense scrub allows the coexistence of different groups of organisms that are bound to specific ecological niches (Plieninger 2006, Kadoyaa \& Washitani 2011). This ecological importance for the region is inextricably linked with its cultural, social and economic relevance. The reconquista and the medieval transhumance system of the Mesta are two historical milestones that have impacted the configuration of the dehesa and led to unique socio-cultural attributes of the region (Ceresuela 1998; Plieninger \& Wildbrand 1999).

This historic legacy needs to be considered in the analysis of recent developments and trends. The overall development of the dehesa in the twentieth century can be divided into three phases. The first phase of the traditional dehesa system, lasted until the mid-1960s (see Parsons 1962). Profound changes of consumption and production patterns lead to the crisis of the dehesa (Diaz et al 1997). Since the early 1990s a revaluation and reorientation of some aspects of the traditional dehesa system has taken place. Both economically and ideologically, this new regime represents the revaluation of the dehesa (Pérez Soba et al. 2007).

Tab. 2 summarizes the general processes of the regime shifts and its consequences for the dehesa system. In terms of land changes, the dehesa crisis caused the most important impacts on the intensity and modes of land-use (Diaz et al. 1997, Joffre et al. 1988). Overgrazing and land degradation became major problems for the dehesa due to the lack of qualified staff. In order to continue to produce efficiently in times of increasing costs and falling prices, livestock breeding was intensified. Pastureland and cultivated land-use also changed, with large areas populated with eucalyptus and pine trees (Rivera 1992).

\begin{tabular}{|c|c|c|}
\hline & General processes & Consequences for the dehesa system \\
\hline Dehesa crisis & $\begin{array}{l}\text { - African Swine Fewer (1963) } \\
\text { - Changing consumption patterns } \\
\text { - Opening of local markets to } \\
\text { lowland products } \\
\text { - Decrease of wool price } \\
\text { - Wage increase in the primary } \\
\text { sector }\end{array}$ & $\begin{array}{l}\text { - Reduction of } 85 \% \text { of total } \\
\text { number of the Iberian Pigs } \\
\text { - Decreasing demand of dehesa } \\
\text { products } \\
\text { - Collapse of the transhumance } \\
\text { - Shift in resource management } \\
\text { (mechanization, abandonment) } \\
\text { - Rural exodus }\end{array}$ \\
\hline $\begin{array}{l}\text { Revaluation of } \\
\text { the dehesa }\end{array}$ & $\begin{array}{l}\text { - Regionalization of agricultural and } \\
\text { environmental competencies } \\
\text { - Spain's accession to the European } \\
\text { Community (1986) } \\
\text { - } \quad \text { CAP-Reform (1992) } \\
\text { - Market stabilisation of dehesa } \\
\text { products (Iberian ham, lamb, cork) }\end{array}$ & $\begin{array}{l}\text { - Promotion of nature } \\
\text { conservation and rural tourism } \\
\text { - Promotion of extensive } \\
\text { livestock breeding } \\
\text { - Forest regeneration } \\
\text { - Higher demand for dehesa } \\
\text { products }\end{array}$ \\
\hline
\end{tabular}

Tab 2. General processes of the regime shifts and its consequences for the dehesa system.

The revaluation phase shows a slighter shift in land-uses and intensities. The 1992 CAP reform, known as the MacSharry reform, was a turning point for the dehesa (Ojeda \& Silva 1997). 
The so called supplementary grants, especially the regulations on "agricultural production methods compatible with the requirements of the protection of the environment and the maintenance of the countryside" (2078/92) and the regulation "instituting a Community aid scheme for forestry measures in agriculture" (2080/92), represented the most important programs for the dehesa. Additionally, extensification premium programs for sheep, goat and cattle breeding had major impacts on the composition and number of these species (Ojeda \& Silva 2002).

The decentralisation process in democratic Spain constituted a breach of the centralised policies in the past. Many sectoral policies such as regional planning, agriculture and environmental conservation were transferred to the Autonomous Regions. The institutional promotion of reforestation with native species and the declaration of numerous natural parks in the mountainous areas of Andalusia have characterised the regional environmental policies of this area (Mulero 2001). Finally, the market for products of the Iberian pig stabilised as the African swine fever in 1994 was overcome and the pig population restored. Demand for other dehesa products, such as veal and lamb meat and goat and sheep cheese, increased (Aguilar 2007).

\section{Results}

With this context in mind, the results of the study are presented to show the impacts on the management practices and land-use dynamics on the local scale, while considering actors and drivers that act and reside on different spatial scales.

\subsection{Typology of land management strategies}

The typology of land management strategies that is represented in tab. 3 focuses on the specific land changes on the farms during crisis and revaluation, the overall attitude of its owners towards the dehesa as a system and their vision of the dehesa development for the future. Four types have been distinguished. Type 1 and 3 correspond to local land-owners, while type 2 and 4 are related to large-estate owners mostly from outside the local context.

The economically powerful caretakers of the dehesas (Type 2) and the disintegrating owners who have transformed diverse dehesa exploitations into monoculture/low diversity hunting reserves or tree plantations (Type 4) represent two types of management strategies implemented by the large-estate owner (latifundios) types. Generally, the latifundio characterizes the dehesa system. It represents dependency relationships in the community (Plieninger et al. 2004) and at the same time, has been a mechanism of social status affirmation and a pathway to have one's property eventually available for financial operations (Rivera 1992).

Its role for dehesa conservation is contested. On the one hand, the latifundios are perceived as a stabilizing factor during the dehesa crisis in the 1960s, as their financial background and their sheer size helped to resist the crisis (ibid.). Of note in this context is the strategy carried out by type 2 as the exception of the general trend of major land changes, especially during the dehesa crisis. The land managers of this type did change management practices during the crisis (fencing the parcels, intensification of livestock breeding, increase in agricultural land), but maintained the land-use pattern and complementary uses. On the other hand, the latifundios are held responsible for the disintegration of the system. They are seen as lacking a genuine interest in the active and innovative use of the dehesa. (Rivera 1992) As mentioned in several interview, they contracted strategic coalitions with the state and companies in order to attain economic benefits through large-scale reforestation with eucalyptus. Finally, they are more interested today in subsidies from the EU as a form of publicly funded investment than they are in the dehesa as an integrated system. A new type of large-estate owners has entered the scene during the last 20 years, attracted by low land prices and the possibility to amortise the investment by public funding that usually fall into type 4 strategies. The overall lack of interest in maintaining the dehesa as an integrated land-use system leads to a simplification or the abandonment of the dehesa. Finally, the low residence time of the landowners accomplishing this type of management strategy has a destabilising effect on the system as whole (Ojeda \& Silva 2002). 
The local landowners (place-based actors) represent the other types of management strategies. They range from long-time residents who are a permanent part of the local rural society (type 3) to new dwellers who are hardly embedded into local social structures but have a strong link to their land and the region (type 1). Type 3 strategies are passive, simplifying reactions to the overall economic situation, while managers who follow type 1 strategies proactively shape the dehesa in order to achieve long-term viability of their exploitation.

\begin{tabular}{|c|c|c|c|c|}
\hline & $\begin{array}{c}\text { Type } 1 \\
\text { (cases } 1,4,6,10)\end{array}$ & $\begin{array}{c}\text { Type } 2 \\
\text { (2) }\end{array}$ & $\begin{array}{l}\text { Type } 3 \\
(3,8,9)\end{array}$ & $\begin{array}{c}\text { Type } 4 \\
(5,7)\end{array}$ \\
\hline 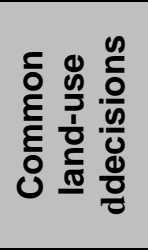 & $\begin{array}{ll}- & \text { Use abandonment } \\
\text { - } & \text { Reforestation with } \\
\text { - } & \text { eucalyptus / fallow } \\
& \text { Innovative re- } \\
& \text { orientation of } \\
& \text { management } \\
\end{array}$ & $\begin{array}{l}\text { Maintenance of } \\
\text { differentiated land- } \\
\text { use due to financial } \\
\text { security } \\
\text { Intensification of } \\
\text { livestock breeding }\end{array}$ & $\begin{array}{ll}\text { - } & \text { Abandonment } \\
\text { of agricultural } \\
\text { use }\end{array}$ & 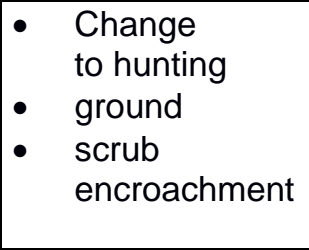 \\
\hline 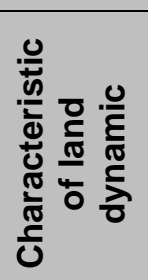 & $\begin{array}{l}\text { Pronounced disruptions } \\
\text { in land-use }\end{array}$ & Stability of land-use & $\begin{array}{l}\text { Simplification of } \\
\text { land-use }\end{array}$ & $\begin{array}{l}\text { Modification of } \\
\text { landuse }\end{array}$ \\
\hline 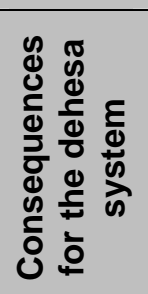 & $\begin{array}{l}\text { Innovation and new } \\
\text { lease of life for } \\
\text { the system }\end{array}$ & Stability of the system & $\begin{array}{l}\text { Simplification of } \\
\text { the system with } \\
\text { degradation } \\
\text { processes }\end{array}$ & $\begin{array}{l}\text { Decompositon of } \\
\text { the System }\end{array}$ \\
\hline 竞 & $\begin{array}{l}\text { New commercialisation } \\
\text { structures and ecological } \\
\text { livestock breeding }\end{array}$ & $\begin{array}{l}\text { Resource } \\
\text { maintenance for future } \\
\text { generations }\end{array}$ & $\begin{array}{l}\text { Property keeping } \\
\text { and survival }\end{array}$ & $\begin{array}{l}\text { Continuation of } \\
\text { hunting }\end{array}$ \\
\hline
\end{tabular}

Tab 3. Characteristics of types of land management strategies.

The initial situation of the traditional dehesa system, as well as the overall driving forces that the land managers have faced, are common to all dehesa land management strategies. The fundamental differences lie in the land tenure and the related financial strength of the farmer. These aspects determine the property size and the differentiation of uses which in turn is reflected in crisis and risk management as well as land-use decision strategies. Concerning the future development of the dehesa the perspective of the land managers is noteworthy. Type 1 and 2 are adaptive, innovative and conservative strategies respectively who may be crucial to the dehesa's conservation and development in a changing political and ecological environment. On the other hand, type 3 is condemned to finding ways to keep the property and survive as agrarian exploitation. One may consider type 4 already to be outside the actual dehesa system in terms of integrated and complementary uses. Its role in the future of the dehesa as a whole is still to be defined.

In more general terms, the interview results point out that significant factors affecting land-use decisions of the different management strategies include agricultural prices, subsidies, natural resource limitations, cultural background, traditions, property rights and access. The land managers pursue two targets: a) profit maximisation by optimally allocating their economic and technological resources and, b) the maintenance of their incomes over a longer period of time by a careful and sustainable use of the natural resources. Thus three main factors guide the decisions: 
- Economic means available to the land manager. If farmers do not depend on profit maximisation for survival they have the opportunity to consider long-term effects of management including the conservation of the existing resources. In a system like the dehesa, this means the generation of long-term revenues. If there is no money to spend in conservation measures and the farmer needs short-term income, the resource base is used more intensively, and the land-use must be changed or abandoned.

- Impact of subsidies on site-level decision-making. The economics of the farms are closely linked to subsidies and other, economic incentives since Spain's accession into the EU. The regional framework (promotion of organic farming, development of cooperatives) or European measures (afforestation policies, agri-environment measures) operate indirectly and for a short time on the decisions.

- Impact of personal values and experiences on decision-making. Individual principles including the preservation of tradition, innovation or short-term speculation are the final background of land-use decisions. Deep-seated values or by external incentives might mark these principles. In this context, the overall concept or vision of future land-use must be identified. Current land managers' decisions are bound both to past appropriation and decisions about and the evolution of natural resources, and to their own vision of conservation and management and their will to innovate and progress (see Plieninger et al. 2004 for dehesas in Extremadura). The economic power is again determining whether the land-use decisions can be made based on this individual vision of resource management.

\subsection{Specific actor constellation of land changes}

The typology of land management strategies led to a GIS-based land-use analysis on selected farms of each type using three series of air photographs $(1956,1984,1999)$. The resulting data was contrasted with the history of the farms, as expressed in the interviews, and put into relation with driving forces and actors on other spatial scales following the analytical framework (see fig. 1). The specific actor constellation of determinate land changes has thrown light on the basic structures of the land management strategies as well as on the particular game the actors and their interests are involved.

As neither the legal and economic state intervention nor corporate activities have considered the dehesa as a whole (Euronatur et al. 2006), the policies and regulation, as well as business strategies, act generally on single components of the dehesa (livestock breeding, agriculture, forestry). The analysis of the forestry component has shown to point out best the driving forces and actors involved, the different responses management strategies on the farm level and the underlying structures of this game (for further details on the Political Ecology of the dynamics of pasture management see Schröder 2005).

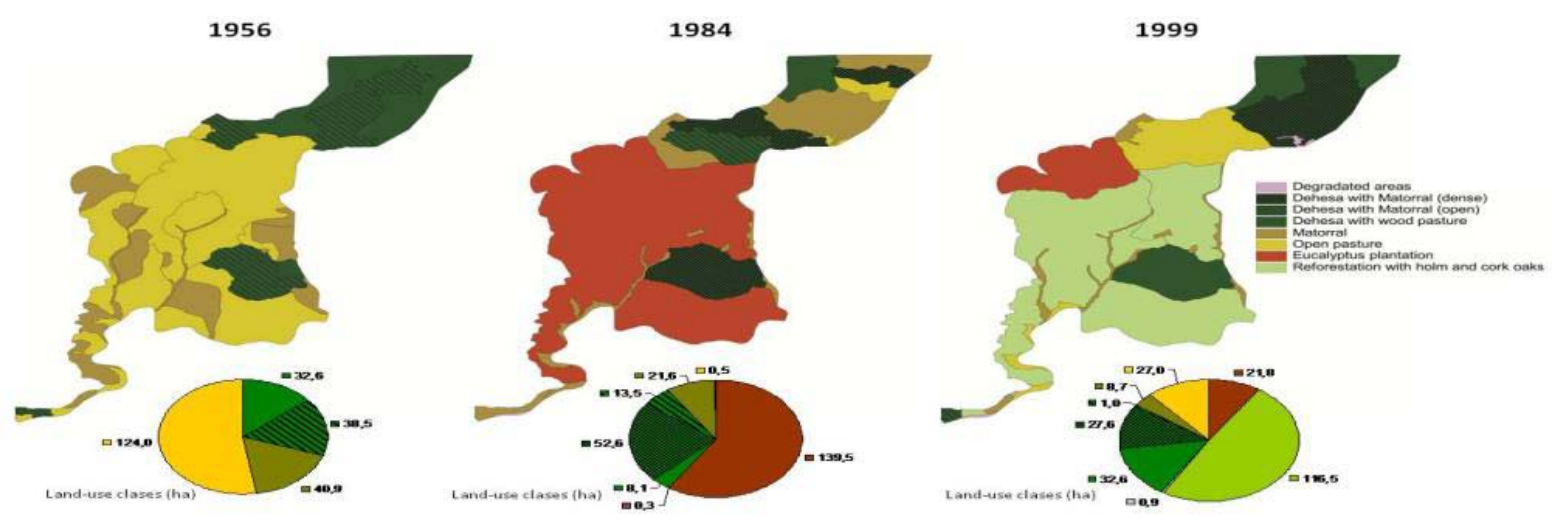

Fig 3. Land change on type 1 farm (cartography and design, C. Schröder). 
As shown in the case of land changes of type 1 (fig 3), two processes can be differentiated in which the state has strongly intervened in the structure and composition of the oak stands over the last 50 years: The phase of the dehesa crisis came along with the afforestation with fast growing and non-native species, such as pine trees and eucalyptus. During the revaluation of the system, the regeneration of tree stands gained in importance and resulted in reforestation with autochthonous species.

In the first phase, against the background of the attempt to achieve autarchy and the constitution of a national wood and paper industry, the national forestry administration (Patrimonio Forestal de España), elaborated in 1939 the General Plan for Reforestation (Plan General de Repoblación Forestal de España). It envisioned the afforestation of six million hectares over the next hundred years. The preferred locations were peripheral and unproductive areas, affected by rural exodus (Ojeda 1989). The farm of the type 1 case, located in the province of Huelva was among these areas. The state-run cellulose factory located in the industrial pole of Huelva exerted an immediate spatial influence over the whole region as more than 200,000 ha were afforested with pine trees (Pinus pinea, Pinus halepensis) and eucalyptus (Eucalyptus globulus) in the province of Huelva (Rivera 1992).

Fig. 4 shows the driving forces and its relationship with local actors over different spatial scales during this phase for type 1 and 4 exploitations. Much afforestation took place on public land, carried out directly by governmental authorities or the timber industry. The leasing of land or part of a property represented another form that many medium-sized farms adopted which is demonstrated in the case of type 1. The economic crisis of the late 1950s and 1960s led to the emigration of the workers and their families and forced the owner to reduce the livestock breeding, simplify the management practices and, finally, to lease more than half of the farm to the cellulose factory in order to plant eucalyptus.

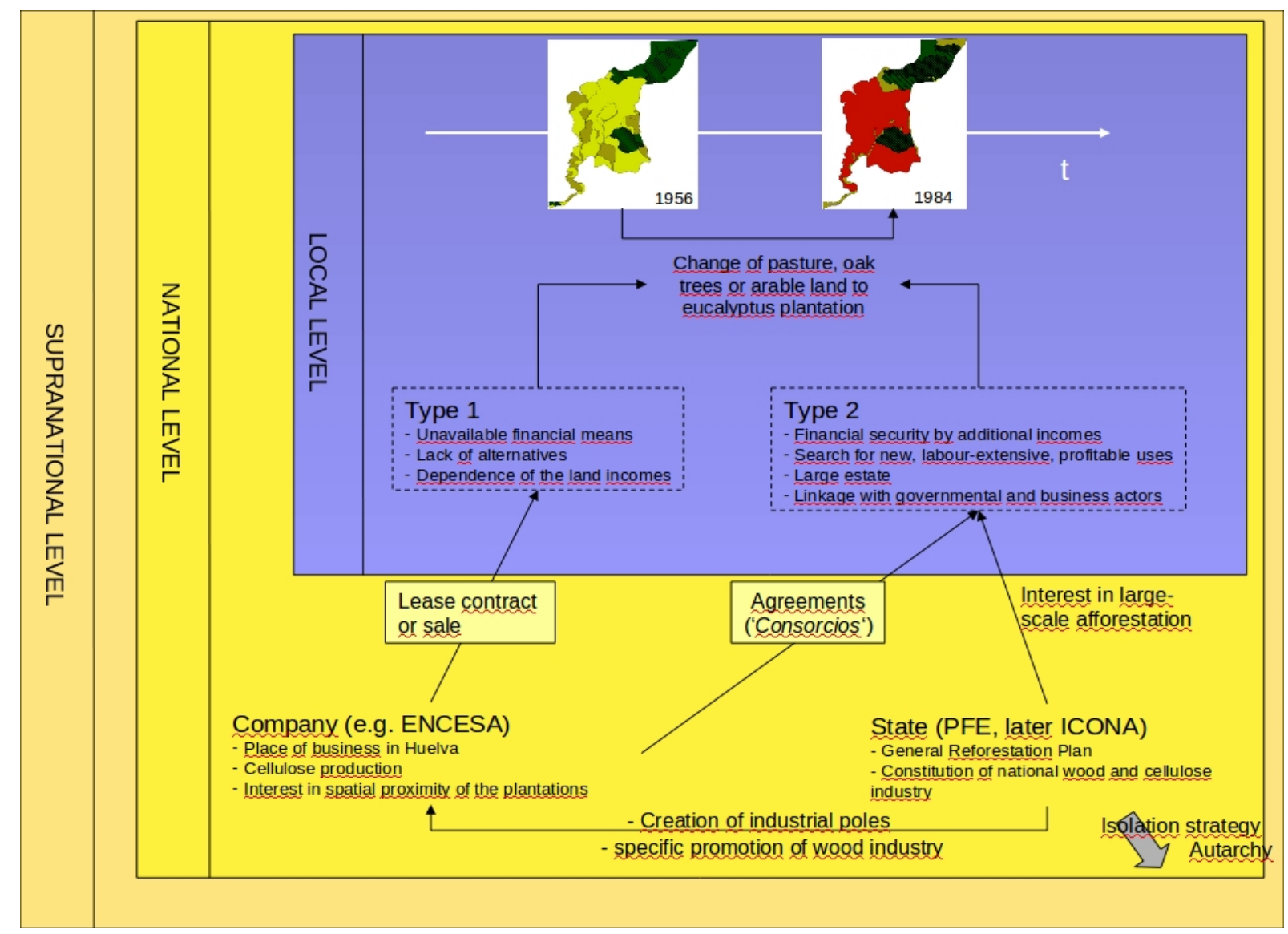

Fig 4. Actor constellation of the eucalyptus afforestation (source: own, after Krings 2000).

Most of the large-estate owners of type 4 instead opted for direct agreements (consorcios) with the state and the cellulose factory, which assured profit. These agreements can be interpreted 
as the formal expression of the interest coalition between the state, the timber and paper industry and the owners (Rivera 1992), leading to a win-win situation: The state was interested in an extensive afforestation, financed by the General Plan for Reforestation, that favoured the constitution and development of a national timber and cellulose industry. The cellulose companies obviously benefited from this strategic orientation and tried to afforest as much as possible, as close as possible to their production sites in Huelva. The latifundios of the western part of the dehesas of the Sierra Morena turned out to be an ideal basis for this strategy as they were located close to the production site, and their size favoured modern and intensive forestry techniques. Furthermore, the afforestation corresponded with the overall interests of many large-estate owners. They did not intend to continue the labour- and management-intensive dehesa system. The agreements relieved them of these difficulties, while their property made a profit. It also constituted a profitable way of property maintenance while facing the danger of loosing their social status because of rural exodus and the economic crisis.

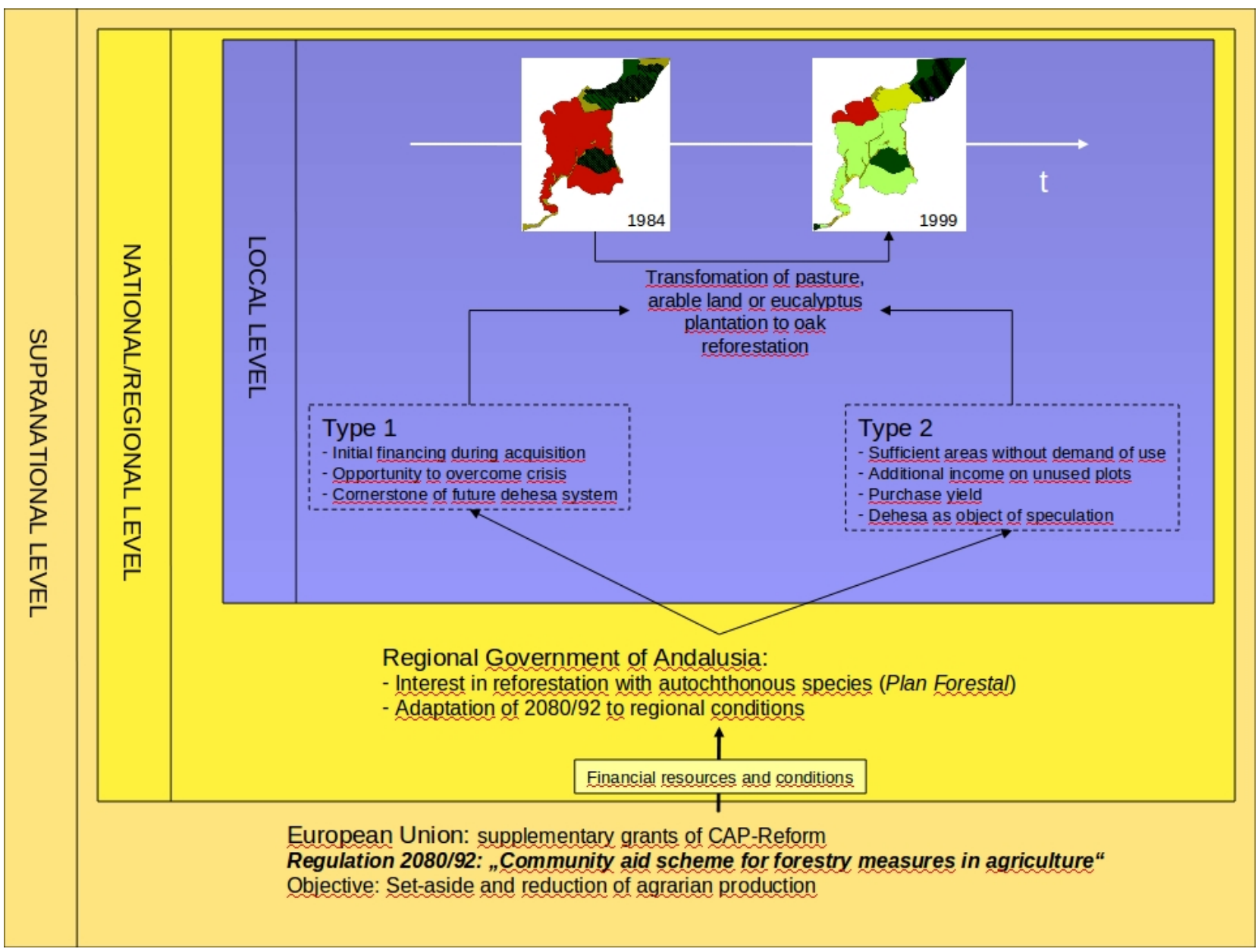

Fig 5. Actor constellation of CAP forestry measures (source: own, after Krings 2000).

With Spain's democratisation in 1978, the responsibility for forest policy shifted from the national to the regional level and from a productive to an environmental perspective (Ojeda 1989). In the course of the MacSharry Reform of the Common Agricultural Policies in 1992 the EURegulation instituting a Community aid scheme for forestry measures in agriculture (2080/92) came into play (Silva 1995). The reforestation competences moved once again from the environmental to the agricultural administration as it pursued objectives of agricultural policies, i.e. reduction of agriculturally productive land, in contrast to forestry or environmental policies. Hence, two reforestation programs are actually in progress. The agricultural administration executes the 2080/92 regulation with an important financial background, while the environmental administration continues the execution of the forestry plan (Ojeda \& Silva 2002). 
From a political ecological point of view, the interests and driving forces involved in this dynamic are numerous (Fig. 5). The long-term transformation of arable land into forests satisfies the interest of both the European agricultural administration and the land managers. It combines the reduction of agricultural land and, thus, production with direct payments over 20 years for land that otherwise would not be profitable. As was stated by the interviewed land managers, similar to the eucalyptus afforestation, the reforestation gives new profitability to the land, especially to latifunidos. This public policy has favoured the colonisation process by external actors (Ojeda \& Silva 2002). On the other hand, the subsidies for reforestation turned out to be the financial means that allowed newcomers like the actual owner of the type 1 case to carry out their management innovations. The subsidies paid for the reforestation of one part of a dehesa constituted a cornerstone for the active and innovative use of the other part of the farm. The landowners of type 1 perceive the regulation and its funds as a crucial opportunity to compensate for the lack of regeneration of oak stands and to build the future of the dehesa.

\section{Discussion}

Political Ecological theory is used to consider environmental problems in developing countries (Bryant and Bailey 1997). Nevertheless, its application to a European context of land change as is the case of the dynamics in the dehesa management concerned with the forestry component has shown to be a valid example, historically and today, of power relations over different spatial scales leading to resource degradation. The application of this approach reveals the profound impact of state policies on different land management strategies. The study unfolds political ecology's complex character, particularly "the inevitable diversity of outcomes and conditions as well as the problematic nature of environmental management regimes premised on inherited assumptions about environmental response, resiliency, and stability" (Turner \& Robbins 2008, p. 304). The local responses to the drivers vary highly revealing that "a cascading web of interactive factors drives land-use/-cover change and (...) the complexity of the interactions, (...) often leads to different land-use outcomes, even under similar initial conditions" (ibid., p. 302).

In contrast to general visions of the dehesa as a historically evolved, stable and sustainable system, the study has revealed a diversity of resource management responses to temporally and spatially differentiated impacts leading to different paths of land-use change. Innovative use of the specific resource basic of the dehesa (type 1) as well as the conservative, stabilizing strategy of type 2 seem to be the most adaptive ways to maintain the dehesas' use and biodiversity. Type 3 and 4 , on the other hand have abandoned the complementary character of the dehesa and fail to maintain the economic and ecological viability of the system.

Economic strength, either based on historic social status or actual subsidies, lays the ground for environmentally sound management practices and long-term perspective of development and conservation. Furthermore, type 1 and 2 show a close relationship with the dehesa system and landscape that is translated into adequate land-use decisions and adaptive management practices, aimed at the preservation of ecosystem services and its intrinsic value. In this context, new players and institutions have emerged that have begun to create new networks within local communities and beyond, to diversify agrarian activities and to promote economic benefits as well as adaptive and collective resource management.

Consequently, further research is required to explore with more detail the local context of the complex socio-ecological system of the dehesas. It should concentrate on local institutions concerned with learning and information interchange, on traditional ecological knowledge as adaptive management (Berkes, Colding \& Folke 2000). Fisher and Fein (2005) state that "(d)egradation often results from a failure to repair and maintain agricultural infrastructure" (p. 66) which in the context of the dehesa may be applied to the lack of maintenance of the resource base. Hence, there is a particular interest in an in-depth study of the direct manipulation practices of the resources and the related institutions in order to fully understand the local resource management and to come up with cases of best practice.

In this context and regarding the European agro-environmental and rural development measures, the strategic guidelines for rural development of the programming period 2007-2013 (European Council 2006) have made important contribution for the application of adequate 
management practices. Axis 2 of these guidelines, "provides measures to protect and enhance natural resources, as well as preserving high-nature value farming and forestry systems and cultural landscapes in Europe's rural areas". Within these measures, "biodiversity and the preservation and development of high nature value farming and forestry system and traditional agricultural landscapes" are one of three EU-level priority areas for the financial resources devoted to axis 2. The dehesas and montados are emblematic examples of high nature value farming systems (Pérez Soba et al. 2007), whereas this change of policy is meant to be a crucial moment for the future of these systems. Nevertheless, it was shown that these measures only can succeed if they fit with local management strategies. Type 1 and 2 are prepared and willing to accomplish these measures as part of their strategic commitment. Type 3 and 4, on the other hand, are either not able or not willing to implement measures of this sort. Regional and national policies and measures should focus on these discrepancies in order to promote good management practices.

The final objective of all these measures has to be the promotion of sustainable rural economies and resilient local communities. The investment in and development of sources of income outside the agricultural sector are the key to give local people in the rural areas new opportunities. As shown in the empirical study, the improvement and diversification of the financial situation of the land managers is crucial to stabilise the landscape dynamics of the dehesa. The attitudes of these land managers in political-economic and environmental contexts are basic factors affecting management and conservation (Fabricius et al. 2007). Their resource management strategies constitute the adaptive character of the dehesa as a whole. These strategies are intrinsically influenced as much by learning, practice, and attitudes as by present market and subsidies (Holling et al. 2002). Already 25 years ago, Vacher et al. (1985) demanded a reorientation of the dehesa management as part of an integrated development of the Mediterranean rural areas. Such development means that the future of the dehesa does not just lie in its function as producer of material goods. Rather, the dehesa must be the central part of the region's rural development and identity, including new components and innovations as some traditional uses are no longer profitable.

\section{Conclusion}

Driving forces ranging from regional to global scales, and their varying historical contexts strongly affect local actors' management strategies. In turn, established management strategies are able to cope with these driving forces resulting in differentiated impacts on the local dehesa dynamics as shown by the results of the political ecological analysis. The most important conclusion is that different paths of land-use change correspond to the high spatial and temporal diversity concerning the strategic responses of different types of management practices to socio-economic changes and politics. This diversity is based on differences in the economic viability, strategic orientation and personal attitudes of the land manager that determine adequate land-use decisions and adaptive management practices. At the same time, new players and institutions have begun to create new networks within local communities and beyond, to diversify agrarian activities and to promote economic benefits as well as adaptive and collective resource management.

The most determining driving forces and actors change from phase to phase. It was shown that during the Franco regime the state was the most influential actor concerning the landscape dynamics of the dehesa of the Sierra Morena. Its impact on the dehesa components through the forestry policy was of special importance. Since Spain's political decentralisation processes and its accession to the European Union, the regional government (Junta de Andalucía) and the European Union have implemented concrete measures in rural areas and have established agricultural and environmental guidelines. Their impact is mainly indirect by using incentives and subsidies. The empirical study has also revealed that the political measures both during the Franco regime and the phase of revaluation as well as the corporate activities are essentially sectoral. Policy reduces the dehesa to an silvopastoral system whereas almost neglects the agricultural component. None of the implicated actors has a holistic vision of the traditionally agrosilvopastoral dehesa system. 
The results indicate that the present European policy for agriculture and local development as well as the endogenous entrepreneurial dynamic are the key factors in the development of the dehesa. The question is how these factors can actively shape the transition of the dehesa system. Several authors assume that the dehesa's productive use is going to be abandoned or to be continued as a relic (Pinto Correira \& Mascarenhas 1999, Vos \& Meekes 1999). Nevertheless, the results have shown a variety of strategic responses that show the adaptive character of the dehesa and its actors. Against the background of the cultural and ecological importance the dehesa has among the Spanish agricultural landscapes, it must be an utmost concern to protect, maintain and develop the dehesa's adaptive capacity. "La dehesa hay que vivirla" (The dehesa must be lived) was one of the repeated conclusion of the land managers. Thus, it is beyond all questions that the transition of an agrosilvopastoral system as the dehesa, based on the utilization of natural resources, has to come along with an active and innovative use. Within this transition, the transmitted social and cultural context of the dehesa system may serve to cope with and adapt to external threats and crises.

\section{Acknowledgements}

This paper was written as a result of a presentation at the international workshop "Socialecological resilience of cultural landscapes", organized by the research group Ecosystem Services at the Berlin-Brandenburg Academy of Science and Humanities. I would like to thank the organizers and participants of the workshop for supportive critique on the presentation, Traci Birge and Prof. Daniel W. Gade for valuable commenting on earlier drafts of the paper and Hirsh Sawhney for improving the language of the paper.

References

[1] Acosta Naranjo, R. (2005): Medio ambiente, grupos sociales y conocimiento local en la dehesa. Un caso de estudio en la Sierra Morena extremeña. Revista de Estudios Agrosociales 206, 63-85.

[2] Aguilar Criado, E. (2007). Productos locales, mercados globales: nuevas dinámicas en el medio rural. In. García Docampo, M. (ed.), Perspectivas Teóricas en Desarrollo Local (pp. 145-169). La Coruña: Netbiblo.

[3] Beaufoy, G. (1995). Distribution of extensive farming systems in Spain. In. McCracken, D. I.; Bignal, E. \& Wenlock, S. E. (eds.). Farming on the edge: the nature of traditional farming in Europe. Proceedings of the Fourth European Forum on Nature Conservation and Pastoralism. (pp. 46-49). Petersborough: Joint Nature Conservation Committee.

[4] Berkes, F, Colding, J. \& Folke, C. (2000). Rediscovery of traditional ecological knowledge as adaptive management. Ecological Applications 10(5), 1251-1262. DOI:10.1890/10510761(2000)010[1251:ROTEKA]2.0.CO;2

[5] Blaikie. P. \& Brookfield, H. C. (eds.) (1987). Land degradation and society. London: Methuen \& Co.

[6] Blondel, J. (2006). The 'design' of Mediterranean landscapes: a millennial story of humans and ecological systems during the historic period. Human Ecology 34, 713-729. DOI: $10.1007 / s 10745-006-9030-4$

[7] Bryant, R. L. \& Bailey, S. (1997). Third world political ecology. London: Routledge.

[8] Caraveli, H. (2000). A comparative analysis on intensification and extensification in Mediterranean agriculture: dilemmas for LFAs policy. Journal of Rural Studies 16(2), 231242. DOI: 10.1016/S0743-0167(99)00050-9

[9] Ceresuela, J. L. (1998). De la dehesa al bosque mediterráneo. In. Hernández DíazAmbrona, C. G. (ed.), La Dehesa: Aprovechamiento sostenible de los recursos naturales (pp. 45-51). Madrid: Editorial Agrícola Española. 
[10] Crumley, C. L. (2007): Historical Ecology: Integrated Thinking at Multiple Temporal and Spatial Scales. In: Hornborg, A. \& Crumley, C.L. (eds.): The World System and The Earth System: Global Socio-Environmental Change and Sustainability since the Neolithic (pp. 15-28). Walnut Creek CA: Left Coast Press.

[11] Díaz, M., Campos Palacín, P. \& Pulido, F. J. (1997). The Spanish dehesas: a diversity in land-use and wildlife. In. Pain, D. J. \& Pienkowsky, M. W. (eds.), Farming and birds in Europe. The Common Agricultural Policy and its implication for bird conservation (pp. 178209) London: Academic Press.

[12] Escobar, A. (1999): After nature: steps to an anti-essentialist political ecology. Current Anthropology, 40(1), 1-30.

[13] Euronatur, Fundación Mediterráneo \& WWF (2006). La dehesa en los Programas de Desarrollo Rural 2007-13: una propuesta independiente. Retrieved March 5, 2011 from http://www.euronatur.org/uploads/media/dehesastudie_200607.pdf).

[14] European Council (2006). 2006/144/EC: Council Decision of 20 february 2006 on Community strategic guidelines for rural development (programming period 2007 to 2013). Official Journal L 055, 25/02/2006 pp. 0020-0029.

[15] Fabricius, C., Folke, C., Cundill, G. \& Schultz, L. (2007). Powerless spectators, coping actors, and adaptive co-managers: a synthesis of the role of communities in ecosystem management. Ecology and Society 12(1). 29. [online] URL: http://www.ecologyandsociety.org/vol12/iss1/art29/

[16] Fernández Ales, R. (1997). La dehesa. In. Jurado Doña, V. (Ed.), Naturaleza de Andalucía. Tomo 7. El medio forestal (pp. 53-72). Sevilla: Ed. Giralda

[17] Fernández Ales, R., Martín, A., Ortega, F. \& Ales, E. E. (1992). Recent changes in landscape structure and function in a Mediterranean region of SW Spain (1950-1984). Landscape and Urban Planning 7(1), 3-18. DOI: 10.1007/BF02573953

[18] Fisher, C. T. \& Feinman, G. M. (2005). Introduction to "Landscapes over Time". American Anthropologist 107(1), 62-69. DOI: 10.1525/aa.2005.107.1.062

[19] García del Barrio, J. M, Bolaños, F., Ortega, M. \& Elena-Roselló, R. (2004). Dynamics of land use and land cover change in dehesa landscapes of the "REDPARES" network between 1956 and 1998. In. Schnabel, S. \& Ferreira, A. (eds.), Sustainability of agrosilvopastoral systems. Dehesas, Montados. Advances in Geoecology 37 (pp. 47-54). Reiskirchen: Catena.

[20] Gastó Coderch, J., Calzado Martínez, C., Carbonero Muñoz, M. D., De Pedro Sanz, E., Fernández Rebollo, P., Garrido Varo, A., Gómez Cabrera, A., Guerrero Ginel, J. E., Guzmán Álvarez, R., Lara Vélez, P. \& Ortiz Medina, L. (2008). Sostenibilidad de las Dehesas. Documento de reflexión. Retrieved March 5, 2011 from http://www.solienses.com/bitacora/DehesaSostenible\%5B1\%5D.pdf

[21] Geist, H. (1999): Exploring the entry points for Political Ecology in the international research agenda on Global Environmental Change. Zeitschrift für Wirtschaftsgeographie 43 (3-4), 158-168.

[22] Graner, E. (1997). The Political Ecology of community forestry in Nepal. Freiburger Studien zur Geographischen Entwicklungsforschung 14. Saarbrücken: Verlag für Entwicklungspolitik.

[23] Hersperger, A. M., Gennaio M., Verburg, P. H., \& Bürgi, M. (2010). Linking land change with driving forces and actors: four conceptual models. Ecology and Society 15(4), 1. [online] URL: http://www.ecologyandsociety.org/vol15/iss4/art1/

[24] Holling, C. S., Gunderson, L. H. \& D. Ludwig (2002): In Quest of a Theory of Adaptive Change. - In: Gunderson, L. H. \& C.S. Holling (eds.): Panarchy. Understanding transformation in human and natural systems (3-22). Washington: Island Press. 
[25] Joffre, R., Vacher, J., de los Llanos, C. \& Gilbert Long (1988). The dehesa: an agrosilvopastoral system of the Mediterranean region with special reference to the Sierra Morena area of Spain. Agroforestry Systems 6(1-3), 71-96. DOI: 10.1007/BF02344747

[26] Kadoyaa, T. \& Washitanib, I. (2011). The Satoyama Index: A biodiversity indicator for agricultural landscapes. Agriculture, Ecosystems and Environment 140, 20-26. DOI:10.1016/j.agee.2010.11.007

[27] Krings, T. (2000). Das politisch-ökologische Analysekonzept in der Umweltforschung. Beispiel der städtischen Brennstoffversorgung in Dakar (Senegal). Geographische Rundschau 52(11), 56-59.

[28] Lambin, E. F. \& Geist, H. (2001). Global land-use and land-cover change: what have we learned so far? IGBP Newsletter 46, 27-30.

[29] Lohnert, B. \& Geist, H. (1999). Endangered ecosystems and coping strategies. Towards a conceptualization of environmental change in the developing world. In. Lohnert, B. \& Geist, H. (eds.), Coping with changing environments. Social dimensions of endangered ecosystems in the developing world. (pp. 1-53) Aldershot: Ashgate.

[30] Marañon, T., Zamora, R. Villar, R., Zavala, M. A., Quero, J. L., Pérez-Ramos, I., Mendoza, I. \& Castro, J. (2004): Regeneration of tree species and restoration under constrasted Mediterranean habitats: field and glasshouse experiments. International Journal of Ecology and Environmental Sciences 30(3), 187-196.

[31] McNeill, J., Alves, D., Arizpe, L., Bykova, O., Galvin, K., Kelmelis, J., Migot-Adholla, S., Morisette, P., Moss, R., Richards, J., Riebsame, W., Sadowski, F., Sanderson, S., Skole, D., Tarr, J., Williams, M. Yadav, S. \& Young, S. (1994). Toward a typology and regionalization of land-cover and land-use change: report of Working Group B. In. Meyer, W. B. \& Turner, B. L. II. (eds.), Changes in land use and land cover. a global perspective. Global Change Institute 4 (pp. 55-72). Cambridge: University Press.

[32] Moreira Madueño, J. M. \& González Fernández, A. (1997). Cartografía y estadística de usos y coberturas vegetales del suelo en Andalucía. 1976-1991. Sevilla: Consejería de Medio Ambiente.

[33] Mulero Mendigorri, A. (2001). Los espacios naturales protegidos en Andalucía: evolución, caracterización geográfica y singularidades. Ería 54-55, 141-157. http://www.revistaeria.es/index.php/eria/article/view/514.

[34] Newman, L. \& Dale, A. (2005): Network Structure, Diversity, and Proactive Resilience Building: a Response to Tompkins and Adger. Ecology and Society 10(1): r2. [online] URL: http://www.ecologyandsociety.org/vol10/iss1/resp2/

[35] Ojeda Rivera, J. F. (1989). El bosque andaluz y su gestión a través de la historia. In. Cano García, G. (eds.), Geografía de Andalucía (pp.315-355). Sevilla: Tartessos.

[36] Ojeda Rivera, J. F. \& Silva Pérez, R. (1997). Dehesas de Sierra Morena y políticas agroambientales comunitarias. Estudios Geográficos 57 (227), 203-226.

[37] Ojeda Rivera, J. F. \& Silva Pérez, R. (2002). Efectos de la implantación del modelo agroambiental y postproductivista en la Sierra Morena onubense. Estudios Geográficos 63(246), 69-100. DOI: 10.3989/egeogr.2002.i246.261

[38] Olea, L. \& San Miguel-Ayanz, A. (2006): The Spanish dehesa. A traditional Mediterranean silvopastoral system linking production and nature conservation. In: Lloveras, J., A. Gonzalez-Rodriguez, O. Vazquez-Yañez, J. Piñeiro, O. Santamaria, L. Olea, \& Poblaciones, M. J. (eds.): Sustainable grassland productivity. Grassland science in Europe (pp. 3-13). Badajoz: Sociedad Española para el Estudio de los Pastos.

[39] Oudenhoven, F. J. W. van, Mijatovi, D. \& Eyzaguirre, P. B. (2010). Bridging managed and natural landscapes. The role of traditional (agri)culture in maintaining the diversity and resilience of social-ecological systems. In. Bélair, C., Ichikawa, K., Wong, B. Y. L. \& 
Mulongoy, K. J. (eds.), Sustainable use of biological diversity in socio-ecological production landscapes. Background to the Satoyama Initiative for the benefit of biodiversity and human well-being. Technical Series 52 (pp. 8-21). Montreal: Secretariat of the Convention on Biological Diversity.

[40] Papanastasis, V. P. (2004). Vegetation degradation and land use changes in agrosilvopastoral systems. In. Schnabel, S. \& Ferreira, A. (eds.), Sustainability of agrosilvopastoral systems. Dehesas, Montados. Advances in Geoecology 37 (pp. 1-12). Reiskirchen: Catena Verlag.

[41] Parejo Delgado, C. (1995). El medio rural en Andalucía. Málaga: Agora.

[42] Parsons, J. J. (1962). The acorn-hog economy of the oak woodlands of southwestern Spain. Geographical Review 52 (2), 211-235. [online] URL: http://www.jstor.org/stable/212957

[43] Peco, B., Oñate, J. J. \& Requena, S. (2001): Dehesa grasslands: natural values, threats and agri-environmental measures in Spain. En: VII European Forum for Nature Conservation and Pastoralism: Recognising European Pastoral Farming Systems and Understanding their Ecology (pp. 37-43). Ennistymon: EFNCP.

[44] Pérez Soba, M., San Miguel A., \& Elena-Rosselló, R. (2007). Complexity in the simplicity: The Spanish Dehesas. In. Pedroli, B., van Doorn, A., de Blust, G., Paracchini, M. L., Wascher, D. \& Bunce, F. (eds.), Europe's living landscapes. Essays on exploring our identity in the countryside (pp. 369-384). Zeist: KNNV.

[45] Pinto Correia, T. \& Mascarenhas, J. (1999). Contribution to the extensification I intensification debate: new trends in the Portuguese montado. Landscape and Urban Planning 46, 125-131. DOI:10.1016/S0169-2046(99)00036-5

[46] Plieninger, T. (2006). Las dehesas de la penillanura cacereña. Origen y evolución de un paisaje cultural. Cáceres: Universidad de Extremadura.

[47] Plieninger, T. \& Hall-Beyer, M. (2007): Traditional land-use and nature conservation in rural Europe. In: Cleveland, C.J. (ed.): Encyclopedia of Earth. Washington, D.C.: Environmental Information Coalition, National Council for Science and the Environment.

[48] Plieninger, T., Höchtl, F. \& Spek, T. (2006): Traditional land-use and nature conservation in European rural landscapes. Environmental Science \& Policy 9, 317-321. Doi:10.1016/j.envsci.2006.03.001

[49] Plieninger, T., Modollel y Mainou, J. \& Konold, W. (2004). Land manager attitudes towards management, regeneration, and conservation of Spanish holm oak savannas (dehesas). Landscape and Urban Planning 66, 185-198. DOI:10.1016/S0169-2046(03)00100-2

[50] Plieninger, T. \& Wildbrand, C. (1999). Die Dehesas in Spanien. - In. Konold, W.; Böcker, R. \& Hampicke, U. (eds.), Handbuch Naturschutz und Landschaftspflege. Kompendium zu Schutz und Entwicklung von Lebensräumen und Landschaften (pp. 1-13). Landsberg: Wiley-VCH.

[51] Pretty, J. \& Ward, H. (2003): Social Capital and the Environment. World Development 29 (2), pp. 209-227.

[52] Rivera Mateos, M. (1992). Explotación agraria y ocupación del espacio productivo en la Sierra Morena. Estudios de Geografía 5. Córdoba: Universidad de Córdoba.

[53] San Miguel Ayanz, A. (1994). La dehesa española. Origen, tipología, características y gestión. Madrid: Fundación Conde del Valle de Salazar.

[54] Schröder, C. (2005). Dinámicas de las Dehesas de Sierra Morena. Sevilla: Consejería de Medio Ambiente.

[55] Silva Pérez, R. (1995): Las acciones forestales en el seno de la PAC. Consecuencias para Andalucía del programa de reforestación. Revista de Estudios Andaluces 21, 85-104. 
[56] Sundseth, K. (2009). Natura 2000 in the Mediterranean Region. Luxembourg: Office for Official Publications of the European Communities.

[57] Swanborn, P. G. (2010). Case study research. What, why and how?. London: Sage.

[58] Turner, B. L. II. \& Robbins, P. (2008). Land-Change Science and Political Ecology: Similarities, Differences, and Implications for Sustainability Science. Annual Review of Environment and Resources 33, 295-316.

DOI: 10.1146/annurev.environ.33.022207.104943

[59] Turner, B. L. II.; Skole, D. L.; Sanderson, S., Fischer, G., Fresco, L. \& Leemans, R. (1995). Land-Use and Land-Cover Change Science/Research Plan. IGBP Report 35 \& IHDP Report 7. Geneva: HDP Secretariat.

[60] Vacher, J., Joffre, R., Ortega, F., Fernandez Ales, R. \& Martin Vicente, A. (1985). L'organisation de l'espace dans la Sierra Norte de Séville (Sierra Morena) et les problème actuels des dehesas. Revue Géographique des Pyrénées et du Sud-Ouest 56(2), 179201.

[61] Vos, W. \& Meekes, H. (1999). Trends in European cultural landscape development: perspectives for a sustainable future. Landscape and Urban Planning 46: 3-14. DOI:10.1016/S0169-2046(99)00043-2

[62] Zavala, M. A. de, Zamora, R., Pulido, F., Blanco, J. A., Bosco Imbert, J., Marañón, T., Castillo, F. J., \& Valladares, F. (2004). Nuevas perspectivas en la conservación, restauración y gestión sostenible del bosque mediterráneo. In. Valladares, F. (ed.), Ecología del bosque mediterráneo en un mundo cambiante (pp. 509-529). Madrid: Ministerio de Medio Ambiente, EGRAF, S. A. 